\title{
The legislative Yuan election, Taiwan 2001
}

\section{Christian Schafferer *}

\author{
Department of International Trade, Overseas Institute of Technology, 100 Chiao Kwang Road, 407 \\ Taichung, Taiwan
}

\section{Introduction}

On 1 December 2001, ten million voters went to the polls in Taiwan to elect the 225 members of the Legislative Yuan, Taiwan's law-making body. The election was a watershed in Taiwan's political development, since the Kuomintang lost its majority in parliament for the first time since the first Legislative Yuan election was held in December 1947. President Chen Shui-bian's Democratic Progressive Party became the largest party in parliament, but fell short of achieving a majority. Nevertheless, it is expected that the DPP will be more successful in pushing through its policies than it was prior to this election.

\section{Background}

In March 2000, Chen Shui-bian of the Democratic Progressive Party (DPP) was elected President of Taiwan. This marked the end of rule by the Kuomintang (KMT) and the beginning of a new era in Taiwan's politics. The KMT candidate, then VicePresident, and Premier Lien Chan, had to admit a major defeat, with Lee Teng-hui, KMT chair and President, forced to resign by angry party members. James Soong, who had left the KMT because of its failure to nominate him as the KMT's presidential candidate, took second place in the presidential election; and soon after formed his own political party, the People First Party (PFP). The PFP was expected to emerge as a third political force in Taiwan's politics. Given that Soong enjoyed far greater popularity than Lien Chan, it was obvious at that point that the KMT would lose its majority in parliament in the upcoming elections. In addition, numerous KMT members withdrew their support in favour of Soong's new party. Chen Shui-bian's presidential victory was seen internationally as a major step towards a consolidated democracy in Taiwan (Freedom House, 2001), a development that was expected to be further consolidated with the 1 December 2001 elections for the Legislative Yuan.

Nevertheless, the DPP faced difficulties in implementing its proposed policies as

* Tel.: +886-920-374239; fax: +886-424-523443.

E-mail address: schafferer@eastasia.at (C. Schafferer). 
parliament was dominated by the 'blue camp' ${ }^{1}$, comprising the KMT, the New Party, and the newly formed PFP. Further, a heated debate over the construction of a fourth nuclear power plant caused a political stalemate that lasted until mid-February 2001 and did much harm to the government as well as the opposition. With the public dissatisfied with the political process but blaming both sides for the stalemate ${ }^{2}$, Lee Teng-hui, the former president, announced his intention to return the country to normality by establishing a new political party, the Taiwan Solidarity Union (TSU). Lee declared that the TSU would support the Chen administration and help the DPP secure a majority in parliament.

Lee's move hurt the KMT badly, and the party responded by expelling Lee and his supporters. Taiwan's media, on the other hand, welcomed Lee's initiative ${ }^{3}$. Political analysts had high expectations that Lee would succeed in helping the ruling DPP to achieve a majority in parliament, especially after his announcement that there would be a number of mainstream KMT legislators either supporting his coalition for national stabilization or changing camps after the election.

Apart from the political disputes, Taiwan's economy was in recession. The GDP shrank considerably throughout the year, with the economists speaking of the deepest GDP decline since the oil crises of the 1970s. Unemployment reached a record high of 5.2\%. The KMT and PFP used Taiwan's poor economy to attack the DPP government and made the economy the issue of the election.

\section{Electoral system}

Prior to recent constitutional reforms in recent years, Taiwan's parliament consisted of three chambers: the law-making Legislative Yuan, the constitution-drafting National Assembly ${ }^{4}$, and a watchdog institution known as the Control Yuan. Members of the first two bodies were elected by universal suffrage; the latter by local council members. The 1997 constitutional amendments excluded the Control Yuan from parliament and increased the number of Legislative Yuan members from 161 to 225. Three-quarters of these seats (168) are elected in 29 geographic constituencies, 25 of which are multi-member districts with an average district magnitude of seven seats. A further eight seats are elected by eight aboriginal tribes in two

\footnotetext{
1 The term 'blue camp' derives from the main colour in the KMT party flag. The 'blue camp' favours re-unification with the People's Republic of China.

2 TVBS Opinion poll: http//tvbs.com.tw/code/tvbsnews/poll/20010521/200110521.asp.

3 The weekly magazine Journalist (6 September, 2001) had a cover story calling Lee 'the father of Taiwan', praising his commitment to a stable and democratic Taiwan nation-state.

4 The term for all National Assembly members expired on 19 May 2000. With effect from that date, 300 Assembly members are to be elected within three months of the expiry of a six-month period following the public announcement of a proposal by the Legislative Yuan to amend the Constitution or to alter the national territory, or within three months of a petition initiated by the Legislative Yuan for the impeachment of the president or the vice-president. Elected members have to convene of their own accord within ten days after confirmation of the election result and have to remain in session not longer than one month, with the term of office expiring on the last day of the convention.
} 
constituencies (with four seats each), which account for less than $2 \%$ of the population. These 176 seats for the multi-member constituencies are elected under a single non-transferable vote (SNTV). The remaining four constituencies-three small islands and the thinly populated county of Taitung-are single-seat constituencies. The remaining 49 seats are distributed proportionally amongst the parties that capture at least $5 \%$ of the total votes cast for party candidates. Eight of these proportionally allocated seats represent the overseas Taiwanese community, and 41 are 'at-large' seats. Further constitutional amendments in May 2000 turned Taiwan's parliament into a semi-bicameral one, with the Legislative Yüan the only chamber regularly elected by universal suffrage.

\section{Electoral campaign}

Taiwan has the most liberal election laws among the region's democracies, with only minor restrictions on campaigning. The law limits the campaign period to ten days and allows each candidate to spend up to NT\$ 7 million. Nonetheless, the political parties and independent candidates usually find loopholes in the law. With Taiwan's economy hard hit by a recession, political analysts predicted a decline in campaign expenditures, but, in fact, the money spent by political parties on advertisements tripled compared with the 1998 elections. The total expenditure by political parties on advertisements in Taiwan's media accounted for NT\$ 826 million; almost half of the amount spent by the KMT, $25 \%$ by PFP, $20 \%$ by DPP, $5 \%$ by TSU, and the remainder by the minor parties. Some $90 \%$ of the total was spent on TV advertisements, 9\% newspaper advertisements, and $1 \%$ in magazines (Rainmaker, 2001).

The economy was the main election issue: The opposition took advantage of the recession and put the blame on the DPP government. Most of their campaign speeches, literature, and advertisements attempted to create the image of the country being on the verge of bankruptcy. The DPP reacted quickly to the accusations. Premier Chang Chun-hsiung responded at a press conference that the DPP had achieved many reforms, which the KMT had been unable to implement during its 50 years in power. He claimed, for instance, that current government policies attempted to balance the development of northern and southern Taiwan, while the KMT had ignored the south. The premier also stressed that although Taiwan's economy was in recession, international surveys, such as the World Competitiveness Report, ranked Taiwan well ahead of other East Asian countries such as Japan, South Korea, and China in terms of competitiveness. The DPP used the opposition's accusations to make counter accusations a major theme in their TV and newspaper advertisements. In a series of televised ads, for instance, the DPP referred to the opposition as 'barbaric and irresponsible budget cutters'. The ads claimed that the KMT and PFP had impeded local development by cutting funds earmarked for public building, child welfare, and computer lessons for children. The message conveyed was that the 'blue camp' was destructive and unreasonable.

Advertising experts criticized the KMT for focusing too much on originality at 
the expense of content. The DPP, on the other hand, were said to be less original but had a clearer message. The good character of chairman James Soong was the major theme of almost all PFP advertisements, which reinforced the impression of the PFP being a one-man band (Cheng, 2001). The Internet was a less important campaign tool than in the 1998 election, when almost every candidate and political party had their own website. This time, few candidates made an effort to create websites, and all major the political parties had less information on their sites than in the previous election.

During the closing days of the ten-day campaign period, President Chen Shuibian made public his idea of a post-election, cross-party alliance for national stabilization. The idea was supported by the TSU and its spiritual leader, former president Lee Teng-hui. Chen also called on the electorate to support the DPP in order to end the dominance of the KMT in the legislature. The 'blue camp', on the other hand, continued to blame the government for the recession, and claimed that only the 'blue camp' could resolve the crisis. Leaders of the 'blue camp' also emphasised in their campaign speeches and leaflets that the relationship with the People's Republic of China had deteriorated under the DPP government; some candidates even claimed that there would soon be war should the DPP be allowed to continue ruling the country.

\section{Results and implications}

The election turned out to be another victory for the DPP and a further serious setback for the KMT. Moreover, for the first time in Taiwan's history, the DPP polled more votes in a national election than the KMT. Voter turnout averaged $66.2 \%$, two percentage points lower than in the 1998 election. About $33 \%$ of the vote went to the DPP; $29 \%$ to the KMT. Compared with 1998, the DPP increased its share by about three percentage points whereas the KMT suffered a heavy loss of 17 points. Public support for the conservative pro-China New Party (NP) plummeted, falling below the $5 \%$ threshold for the 'at-large' seats. The PFP, on the other hand, was another big winner in this election, polling $19 \%$ of the vote; the TSU passed the 5\% threshold as expected. See Table 1.

Of the 12 political parties competing in the election, six won at least one seat and four met the criteria for the proportional representation seats. The DPP captured 87 seats altogether: 69 in the geographic constituencies, 15 'at-large' seats, and three of the eight seats representing overseas Taiwanese. A total of 68 seats were taken by the KMT: 49 in geographic constituencies, 13 'at-large' seats, four aboriginal seats, and two of the seats representing the overseas Taiwanese. The TSU won 13 seats: eight in geographic constituencies, four 'at-large' seats, and one for the overseas Taiwanese. The NP captured only one seat, on the offshore island of Kinmen, and the Taiwan No. 1 Party (TN1) won one in the aboriginal constituency. Independent candidates took eight seats in geographic constituencies and one in the aboriginal constituencies.

Compared with the 1998 election, the DPP increased its seats from 70-87; the 
Table 1

Vote share in the Legislative Yuan elections, Taiwan, 2001 and $1998^{\mathrm{a}}$

\begin{tabular}{|c|c|c|c|c|}
\hline Affiliation & $\begin{array}{l}2001 \\
\text { Votes }\end{array}$ & $\%$ & $\begin{array}{l}1998 \\
\text { Votes }\end{array}$ & $\%$ \\
\hline DPP & $3,447,740$ & 33.4 & $2,966,834$ & 29.6 \\
\hline KMT & $2,949,371$ & 28.6 & $4,659,679$ & 46.4 \\
\hline PFP & $1,917,836$ & 18.6 & - & - \\
\hline TSU & 801,560 & 7.8 & - & - \\
\hline NP & 269,620 & 2.6 & 708,465 & 7.1 \\
\hline Independents & 899,254 & 8.7 & 946,431 & 9.4 \\
\hline Other parties & 42,474 & 0.4 & 754,420 & 7.5 \\
\hline Total & $10,327,855$ & 100.0 & $10,035,829$ & 100.0 \\
\hline
\end{tabular}

a Source: Central Election Commission, Ministry of Interior, Taiwan

KMT lost almost half its 1998 seats, and the NP lost 10 of the 11 seats won in 1998. The TSU was the only party to have intentionally nominated far too many candidates, which it did in an attempt to enhance its chances of passing the 5\% threshold for the 'at-large' seats. In all, 455 candidates contested in 29 geographic and two aboriginal constituencies. See Table 2.

The KMT lost the election because of its highly unpopular leader, Lien Chan, and the emergence of the PFP. In addition, candidates of the 'blue camp', in general, could not benefit from the issue of cross-straits relations in this election, since the People's Republic of China refrained from interfering: The Chinese media did not even report on the election.

Moreover, the KMT's electoral strategies did not work as well as those of the DPP. Winning seats in the 27 multi-member constituencies-25 geographic constitu-

Table 2

Seat distribution following the Legislative Yuan elections, Taiwan, 2001 and $1998^{\mathrm{a}}$

\begin{tabular}{lrcrc}
\hline & \multicolumn{2}{c}{$\begin{array}{l}\text { 2001 } \\
\text { Seats }\end{array}$} & $\begin{array}{l}\text { \% of successful } \\
\text { Seats } \\
\text { candidates }\end{array}$ & $\begin{array}{l}\text { \% of successful } \\
\text { candidates }\end{array}$ \\
\hline DPP & 87 & 77.5 & 70 & 65.8 \\
KMT & 68 & 54.6 & 123 & 73.9 \\
PFP & 46 & 57.4 & - & - \\
TSU & 13 & 20.5 & - & - \\
NP & 1 & 3.0 & 11 & 19.4 \\
TN1 & 1 & 33.3 & - & 11.1 \\
Independents & 9 & 6.8 & 12 & 9.9 \\
Other parties & - & - & 9 & 47.6 \\
Total & 225 & 41.5 & 225 & \\
\hline
\end{tabular}

\footnotetext{
a Source: Central Election Commission, Ministry of Interior, Taiwan
} 
encies and two aboriginal constituencies — requires each party to calculate how many votes it could reasonably hope to poll in any constituency in order to minimize the number of lost votes. In this election, the KMT nominated far too many candidates in key constituencies, such as in Taipei City. Moreover, the party network did not support every candidate with the same degree of enthusiasm. Rather, the party supported candidates with the higher popularity ratings in opinion surveys. The DPP, on the other hand, has for a long time practiced the so-called pei piao system (forced vote distribution). In this election, for instance, the DPP nominated five candidates for the second district in Taipei City, and gave each of its five candidates two singledigit numbers: i.e. zero and one to the first candidate, two and three to the second, and so forth. Party supporters were urged to vote for the candidate whose numbers coincided with the last digit of their National Identity Number ${ }^{5}$ If most DPP supporters followed the strategy, each candidate should receive an equal number of votes $^{6}$. The pei piao system has been regarded as one of the key reasons for the party's success in this election.

A further factor contributing to the success of the DPP was President Chen Shuibian's promise that there would be a more efficient government if the people gave the DPP a majority in parliament. In addition, the electorate in general did not believe Lien Chan's claim that he would revive Taiwan's economy, especially after a press conference where he had to admit that the KMT's economic policies did not differ much from those of the DPP.

The election gave the 'green camp" (comprising DPP and TSU) a so-called 'working majority': 100 out of 225 seats. But when the former president and spiritual leader of TSU, Lee Teng-hui, announced that several independents, along with some KMT and PFP legislators, would support the 'green camp', it secured a de facto majority in the Legislative Yuan. This gives rise to optimism that a strengthened DPP government will be more likely to implement its policies this time.

\section{References}

Cheng, T., 2001. Mudslinging, no beef in sight. Brain 308 (1), 24-29.

Freedom House, 2001. Freedom in the World. http://216.119.117.183/research/freeworld/2001/table1.htm. 4 December 2001.

Pao, C., 1998. The effectiveness of the New Party's strategy of forced vote distribution in the 1995 legislative election. Electoral Studies 5 (1), 95-138.

Rainmaker, 2001. Report on Ad Spending Parliamentary Election. Taipei.

0261-3794/02/\$ - see front matter (C) 2002 Elsevier Science Ltd. All rights reserved. doi:10.1016/S0261-3794(02)00068-9

\footnotetext{
5 Similar to the social security number in other countries.

${ }^{6}$ The NP used the same system in the 1995 parliamentary election in the city of Taipei and in the counties of Taipei and Taoyuan. As a result, 12 of their 14 candidates were elected (Pao, 1998).

7 The term 'green camp' derives from the main colour in the DPP party flag. The 'green camp' is not interested in re-unification with China.
} 